\title{
Humoral and Cellular Response of Pheasants Vaccinated against Newcastle Disease and Haemorrhagic Enteritis
}

\author{
S. GRACZYK, A. WIELICZKO ${ }^{1}$, A. PLISZCZAK-KRÓL, B. JANACZYK \\ Division of Pathophysiology at the Department of Pathological Anatomy, Pathophysiology, Microbiology and \\ Forensic Veterinary Medicine; \\ ${ }^{1}$ Department of Epizootiology and Administration with Clinic, Faculty of Veterinary Medicine, Agricultural \\ University of Wroclaw, Wroclaw, Poland \\ Received December 30, 2005 \\ Accepted April 13, 2006
}

\begin{abstract}
Graczyk S., A. Wieliczko, A. Pliszczak-Król, B. Janaczyk: Humoral and Cellular Response of Pheasants Vaccinated against Newcastle Disease and Haemorrhagic Enteritis. Acta Vet Brno 75, 2006: 379-386.

The purpose of the experiment was to define whether and to what extent can prophylactic vaccinations against Newcastle disease (ND) and haemorrhagic enteritis (HE) affect the humoral and cellular response in pheasants. The evaluation of humoral response was performed on a basis of agglutinin titre after administered antigen and the cellular immunity index was the delayed type hypersensitivity (DTH) reaction. The pheasants were prophylactically vaccinated against Newcastle Disease (ND) on the $1^{\text {st }}, 28^{\text {th }}$ and $56^{\text {th }}$ day of life. Moreover, on the $49^{\text {th }}$ day of life, part of the birds was given in the drinking water a vaccine containing the HEV (Haemorrhagic Enteritis Virus). Fourteen days after the HEV vaccination, the birds were intravenously given $0.5 \mathrm{ml}$ of the $10 \%$ SRBC (sheep red blood cells) suspension. Simultaneously with the SRBC administration the delayed hypersensitivity test was performed by intradermal administration of phytohaemagglutinin (PHA). It was shown that in pheasants vaccinated with NDV and additionally with HEV, the specific agglutinin anti-SRBC titre was significantly $(p<0.05)$ lower than in birds vaccinated against ND only. It also appeared that, the antibodies resistant to 2-mercaptoethanol were $43 \%$ of the total pool of specific anti-SRBC antibodies in the NDV vaccinated birds, whereas in birds vaccinated also with HEV they were $75 \%$. No significant differences were found in the DTH test. Only in the HEV vaccinated pheasants the tendency to increase the wing index value was noted. The results confirm the observations concerning immunosuppressive effects of simultaneous vaccinations. They also indicate that overloading the pheasants with many antigens (ND and HEV vaccination) may weaken the humoral response to administered SRBC.
\end{abstract}

HEV vaccination, NDV vaccination, anti-SRBC antibody titre, delayed type hypersensitivity (DTH), pheasants

The main role of the immune system is to distinguish between what is its own and what is foreign and to eliminate any threat that may impair homeostasis. The threat is recognized much faster when the factor causing it is known. This knowledge has been used in prevention of animal infectious diseases for years, hence, the use of vaccines containing attenuated pathogenic antigens (Ahmad and Sharma 1993; Pierson and Fitzgerald 2003). The rate and quality of the response depend on animal species and individual cases. In birds, this is influenced by numerous factors, mainly genetic, resulting from natural selection or breeding conditions provided (Kunze et al. 1996; B oa-Amponsem et al. 1999; Talebi et al. 2005). Practically, the key role is attributed to environmental conditions, understood in a very broad sense. As has been shown, the transfer of wild animals into any housing system brings about the threat of increased susceptibility to bacterial and viral diseases. According to many researchers, the increased susceptibility of birds to infectious diseases is an effect of various immunosuppressors (Dohms and Metz 1991; Pierson et al. 1996; Boa-Amponsem et al. 1999; Rautenschlein and Sharma 1999).

Address for correspondence:

prof. dr hab. Stanisłav Graczyk

Faculty of Veterinary Medicine

ul. Norwida 31

50-375 Wrocław

E-mail: graczyk@ozi.ar.wroc.pl

http://www.vfu.cz/acta-vet/actavet.htm 
Among the viruses deteriorating the reactivity of the immune system in birds there are adenoviruses, such as MSDV - Marble Spleen Disease Virus, commonly found in pheasants. It is a type II avian adenovirus closely related to the haemorrhagic enteritis virus HEV- Haemorrhagic Enteritis Virus and AAS - Avian Adenovirus Splenomegaly (Domermuth et al. 1979; Fitzgerald and Reed 1989; Pierson and Fitzgerald 2003). Infections caused by these viruses are very common. In Poland, the presence of specific anti-HEV anitbodies in ring-necked pheasants (Phasianus colchicus L.) was found in $66.7 \%$ of flocks under investigation (Wieliczko et al. 2003). These infections usually show no symptoms, but consequently lead to immunosuppression. As a result, the reticuloendothelial cells are damaged, especially in the spleen, which is enlarged and marble-like due to hyperplasia of the white pulp. Morphological changes were also observed in bursa of Fabricius, liver, caecal tonsils and kidneys (Gross 1967; Carlson et al. 1974; Trampel 1992). According to Nagaraja et al. (1982), immunosuppression caused by the HE virus is temporary. However, it may cause secondary infections, especially with E. coli or coccidia (Sponenberg et al. 1985; Pierson et al. 1996). Some authors report that immunosuppression can also be caused by vaccines containing attenuated viruses (Rautenschlein and Sharma 1999; Kulikova et al. 2004). The mechanisms of immunosuppression are still not well known.

Bearing in mind the facts described above, we evaluated the reactivity of the immune system in pheasants vaccinated against Newcastle disease (ND), and additionally, prophylactically immunized with a vaccine containing a living, attenuated Haemorrhagic Enteritis Virus (HEV).

The criterion for a humoral response assessment in pheasants was the anti-SRBC (sheep red blood cells) haemagglutinin titre. Cellular response was assessed using a delayed type hypersensitivity test (DTH), after intradermal injection of a T-cell mitogen.

\section{Materials and Methods}

Experimental procedure

The material taken for the study consisted of 40 pheasants, male and female, purchased from a pheasantry when they were one day old. After several days, the birds were divided into four groups (with the same number of pheasants each) and put in separate cages. All the birds were fed ad libitum a complete mixture for pheasants and had free access to water. For the entire experimental period, the birds were fed the same diet and were provided with identical zoohygienic conditions. All the pheasants, one day of age, were prophylactically vaccinated against ND using spray with a Pestos vaccine (Merial), and next, on days 28 and 56 of age, they were given Sotasec vaccine (Merial) in drinking water, according to manufacturers' recommendations. Moreover, 49-day-old birds in groups 3 and 4 were given drinking water containing Dindoral SPF (Merial), a commercial vaccine with Domermuth HEV strain. It is usually recommended for active immunization of turkey broilers (against HEV) and pheasants (against MSDV).

On day 63 of the experiment, i.e. 14 days after HEV vaccination, the birds in groups 2 and 4 were intravenously injected with $0.5 \mathrm{ml}$ of $10 \%$ SRBC, suspended in PBS. The experimental procedure comprised the following groups:

\begin{tabular}{|c|c|c|c|}
\hline Group 1 & Group 2 & Group 3 & Group 4 \\
\hline $\begin{array}{c}\text { NDV vaccinated } \\
\text { pheasants }\end{array}$ & $\begin{array}{c}\text { NDV + SRBC } \\
\text { vaccinated pheasants }\end{array}$ & $\begin{array}{c}\text { NDV + HEV } \\
\text { vaccinated pheasants }\end{array}$ & $\begin{array}{c}\text { NDV + HEV + SRBC } \\
\text { vaccinated pheasants }\end{array}$ \\
\hline
\end{tabular}

Simultaneously with SRBC immunization, the HEV vaccinated and non-vaccinated birds were tested, using a delayed type hypersensitivity test (DTH), according to the procedure described by Parmentier et al. (1998) and Graczyk et al. (1998, 2004). The left wing web was injected with $0.1 \mathrm{~cm}^{3}$ of PHA - (DIFCO LAB $-1000 \mu \mathrm{g} / \mathrm{cm}^{3}$ ). The same procedure was used for the right wing, which was injected with PBS (control group).

For comparison, the same dose of PHA was injected intradermally, into the skin, between the third and fourth digits of the right foot. The skin thickness was measured, using a micrometer, exactly in the PBS- and PHA-injected areas, before and $24 \mathrm{~h}$ after injection. The magnitude of response was determined by calculating the wing and toe indexes (WI, TI) as the difference in the skin thickness, before and $24 \mathrm{~h}$ after intradermal injections. 
Serological procedure

The presence of anti-NDV antibodies was performed by the haemagglutination inhibition test (HI test) using an antigen produced by the State Veterinary Institute in Pulawy (Instruction No. GIWZ VII-420/lab-2/2003 on diagnostic tests for Newcastle Disease). The tests were done using blood samples collected from the wing vein of 63-, 70- and 84-day-old birds (i.e. on days 14, 21 and 35 after HEV vaccination). The HI was determined, using twofold increasing dilutions of the serum and a constant dose of ND antigen containing 4 units of HA in 25 ml. The highest dilution of serum, in which haemagglutination was inhibited completely, was accepted as the titre. The HI titre was considered positive when the serum dilution 1:16 and higher inhibited $4 \mathrm{HA}$ antigen units. The results of $\mathrm{HI}$ reactivity were accepted as the mean of $\mathrm{HI}$ titres for a group expressed in $\log _{2}$.

The efficacy of $\mathrm{HE}$ vaccination was evaluated with regard to the presence of specific anti-HEV antibodies in pheasants' serum obtained from blood collected from the wing vein of 63-, 70- and 84-day-old birds (i.e. 14, 21 and 35 days after HEV vaccination).

The presence of specific anti-HEV antibodies was determined, using precipitation reaction in agar gel (AGP), with the use of pheasant serum and HE antigen (Spafas, USA). The AGP test was performed using Noble Difco agar, in parallel for the investigated sera and also using positive HE Reagent Serum (Spafas, USA). The result was read 24 and $48 \mathrm{~h}$ after incubation in a humid chamber at $25^{\circ} \mathrm{C}$.

Humoral response to SRBC was evaluated, taking into account the titres of specific agglutinins present in the serum, examined 21 days after HEV vaccination, i.e. 7 days after SRBC immunization. The serum of pheasants, used for determining total anti-SRBC agglutinin titre, was also used to determine the level of antibodies resistant to 2-mercaptoethanol (2-ME-resistant) (Graczyk et al. 2000).

The results obtained in the study were analyzed statistically, using Student's $t$-test. The differences were considered significant at $p<0.05$.

\section{Results}

Table 1 shows the efficiency of prophylactic vaccination, based on the level or presence of specific antibodies.

The presence of specific anti-NDV antibodies was found in $75 \%$ to $100 \%$ ND-vaccinated pheasants, tested 14 days after HEV vaccination. When the tests were repeated 21 and 35 days after vaccination, the anti-NDV antibodies were present in all the birds. However, the antibody titres were consequently increasing with consecutive blood collections. With the tendency maintained and a lapse of time after vaccination, the absolute value of the titre varied in different groups of birds. The highest titre $\left(6.4 \log _{2}\right)$ was found in group 1 (NDVvaccinated), and a comparable level $\left(5.8 \log _{2}\right)$ was found in group 2 (NDV-vaccinated and SRBC-immunized). However, NDV- and HEV-, and to a larger extent, NDV- and HEVvaccinated + SRBC-immunized pheasants exhibited the antibody titre at a markedly lower level as compared with non-vaccinated birds, i.e. $4.8 \log _{2}$ and $4.6 \log _{2}$, respectively (Table 1, Fig. 1).

The analysis of the anti-HEV antibody presence in serum showed their lack in birds nonvaccinated with $\mathrm{HEV}$ and their presence in all vaccinated birds, but not earlier than 21 days after vaccination (Table 1).

On day 7 after SRBC immunization, the mean specific anti-SRBC agglutinin titre in group 2 was 1:588 (g - 512). In contrast, in group 4 (HEV-vaccinated earlier) it was 1:154 $(g-135)$, that is, significantly $(p<0.05)$ lower. Besides, in group 2 , over $40 \%$ of all specific agglutinins were resistant to 2- mercaptoethanol (IgG), while 2-ME resistant antibodies in HEV- and SRBC-immunized birds (group 4) accounted for 75\% (Table 2) .

The mean values of the wing index (WI) and the toe index (TI) are shown in Table 3. The data show that the response to the administered mitogen (PHA) did not result in any significant differences in WI between the control and HEV-vaccinated birds. Similar relations were observed with TI, however, the absolute TI value was twice lower than that of WI (Table 3).

\section{Discussion}

The purpose of the present experiment was to study whether and to what extent can prophylactic vaccines containing attenuated NDV and HEV affect the response of the immune system in pheasants, including a cellular response to non-proliferating SRBC and 
Table 1. The anti-NDV antibodies titre ( $\log _{2}$ of $\mathrm{HI}$ titre) and anti-HEV antibodies presence in blood serum of the experimental pheasants.

\begin{tabular}{|c|c|c|c|c|}
\hline \multirow[b]{2}{*}{ GROUP } & \multirow[b]{2}{*}{$\begin{array}{c}\text { days after } \\
\text { vaccination }\end{array}$} & \multicolumn{2}{|c|}{ anti-NDV antibodies } & \multirow{2}{*}{$\begin{array}{c}\begin{array}{l}\text { anti-HEV } \\
\text { antibodies }\end{array} \\
\text { AGP** }\end{array}$} \\
\hline & & $\begin{array}{c}\mathrm{N} \text { - samples } \\
\text { number } \\
\text { (\% of positive) }\end{array}$ & $\begin{array}{c}\text { GMT* } \\
-\left(\log _{2}\right) \text { range }\end{array}$ & \\
\hline \multirow[t]{3}{*}{$1-\mathrm{ND}$} & 14 & $8(100.0)$ & $\begin{array}{c}5.3 \\
(3-6)\end{array}$ & $0 / 10$ \\
\hline & 21 & $8(100.0)$ & $\begin{array}{c}5.9 \\
(5-7)\end{array}$ & $0 / 10$ \\
\hline & 35 & $8(100.0)$ & $\begin{array}{c}6.4 \\
(5-8) \\
\end{array}$ & $0 / 10$ \\
\hline \multirow[t]{3}{*}{$2-\mathrm{ND}+\mathrm{SRBC}$} & 14 & $8(100.0)$ & $\begin{array}{c}5.0 \\
(4-6) \\
\end{array}$ & $0 / 10$ \\
\hline & 21 & $8(100.0)$ & $\begin{array}{c}5.8 \\
(5-7)\end{array}$ & $0 / 10$ \\
\hline & 35 & $8(100.0)$ & $\begin{array}{c}5.8 \\
(5-7) \\
\end{array}$ & $0 / 10$ \\
\hline \multirow[t]{3}{*}{3 - ND + HEV } & 14 & $7(87.5)$ & $\begin{array}{c}4.3 \\
(3-5)\end{array}$ & $6 / 10$ \\
\hline & 21 & $8(100.0)$ & $\begin{array}{c}4.6 \\
(4-5) \\
\end{array}$ & $10 / 10$ \\
\hline & 35 & $8(100.0)$ & $\begin{array}{c}4.8 \\
(4-5)\end{array}$ & $10 / 10$ \\
\hline \multirow[t]{3}{*}{$\begin{array}{c}4-\mathrm{ND}+\mathrm{HEV} \\
+\mathrm{SRBC}\end{array}$} & 14 & $6(75.0)$ & $\begin{array}{c}4.1 \\
(3-5)\end{array}$ & $7 / 10$ \\
\hline & 21 & $8(100.0)$ & $\begin{array}{c}4.4 \\
(3-5) \\
\end{array}$ & $10 / 10$ \\
\hline & 35 & $8(100.0)$ & $\begin{array}{c}4.6 \\
(4-6)\end{array}$ & $10 / 10$ \\
\hline
\end{tabular}

Explanations:

*- GMT geometric mean of the HI titre (titre demonstrated as $\log _{2}$ );

** in numerator - the number of positive samples, in denominator - the number of investigated samples

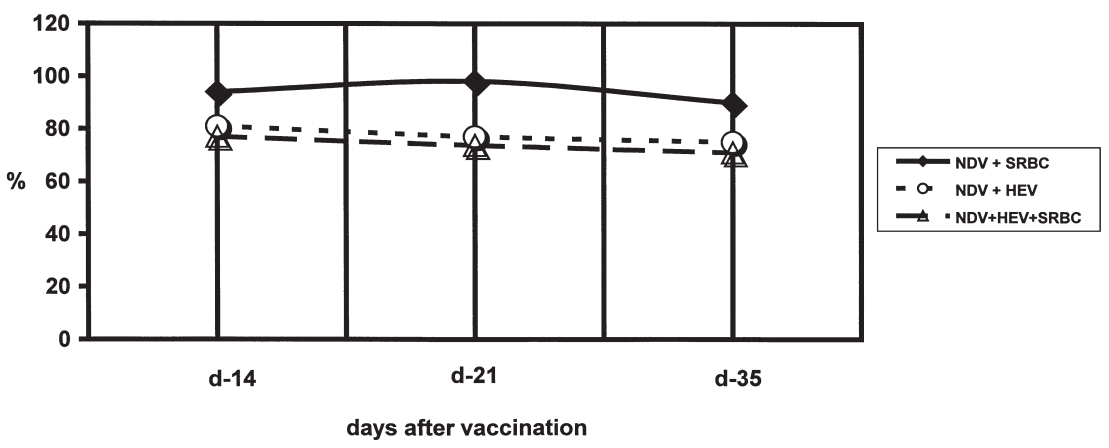

Fig. 1. The anti-NVD antibodies titre in the blood serum of the experimental pheasants ( shown as \% of the values noted in control group) 
Table 2. Anti-SRBC antibodies titre in the blood serum of experimental pheasants.

\begin{tabular}{|c|c|c|}
\hline GROUP & $\begin{array}{c}\text { Mean antibody titre } \\
(\text { total })\end{array}$ & $\begin{array}{c}\text { Mean antibody titre } \\
(2-M E-r e s i s t a n t)\end{array}$ \\
\hline $\mathbf{2}$ & $588.8 \pm 320.42$ & $256 \pm 94.53$ \\
\hline $\mathbf{N D V}+\mathrm{SRBC})$ & & $116.36^{*} \pm 78.73$ \\
\hline
\end{tabular}

* - statistically significant difference at $p<0.05$

Table 3. Mean values of the wing and toe indexes in experimental pheasants (DTH test)

\begin{tabular}{|c|c|c|}
\hline Birds & $\begin{array}{c}\text { Wing index }(\mathrm{WI}) \\
(\mathrm{mm})\end{array}$ & $\begin{array}{c}\text { Toe index }(\mathrm{TI}) \\
(\mathrm{mm})\end{array}$ \\
\hline Non-HEV-vaccinated pheasants & $2.12 \pm 0.57$ & $0.96 \pm 0.30$ \\
\hline HEV vaccinated pheasants & $2.39 \pm 0.77$ & $1.18 \pm 1.06$ \\
\hline
\end{tabular}

* - statistically significant difference at $p<0.05$

antibody levels. An almost fourfold decrease in anti-SRBC antibody titre observed in pheasants vaccinated with NDV + HEV as compared to NDV-vaccinated birds, accounts for a suppressive action of HEV.

The interaction of various antigens, including living or attenuated vaccines has been studied extensively for many years, but the results obtained show discrepancies (Slowik et al. 1990; Sharma 1994; Pierson et al. 1996; Rautenschlein and Sharma 1999; Ganapathy et al. 2005).

Slowik et al. (1990) found a twofold increase in anti-NDV antibody titre after additional SRBC stimulation of chickens and a decreasing titre after BSA administration. At the same time, they did not observe any impact of NDV vaccination on the specific anti-SRBC agglutinin titre. Gan a pathy et al. (2005) reported that SPF chickens vaccinated with living APV and NDV exhibited temporary suppression of APV proliferation and inhibited production of specific antibodies. This corresponded with increased levels of anti-NDV antibody titres in chickens. Some authors even suggest that administration of various vaccines at short-time intervals may result in temporary changes in the immune system, which may be favourable for the development of secondary infections (Piers on et al. 1996; Rautenschlein and Sharma 1999).

The decreased anti-SRBC antibody titre observed in HEV-vaccinated pheasants is therefore in agreement with the observations of the authors cited above, and besides, it shows that simultaneous vaccination can enhance pathogenicity of the vaccines administered. It is also worth noting that anti-NDV antibody titre in NDV + HEV-vaccinated pheasants was over $20 \%$ lower than that observed in the pheasants vaccinated only with NDV. Additional SRBC stimulation of the birds enhanced the suppressive effect of HEV, which suggests that immunosuppression is not directed towards a definite antigen. On the other hand, simultaneous vaccination did not have a significant impact on antibody levels, observed in consecutive blood samples after vaccination. Due to the fact that our experiment was focused only on the presence of anti-HEV antibodies, excluding the titre, it was impossible to assess the influence of NDV on anti- HEV antibody titre. Other interesting results obtained in our study were connected with a changing quality of anti-SRBC antibodies, since HEV-vaccinated birds exhibited augmented percentages of 2-ME resistant antibodies. A direct mechanism responsible for the change of class of the synthetized antibodies is, at this stage of research, difficult to explain. 
The studies of HE pathogenesis show that the immune system, which is connected with antibody production, plays an important part in the development of a disease. Sure sh and Sharma (1995) studied turkeys inoculated with HEV and found a significant depletion of $\operatorname{IgM}+$ cells. On the other hand, the studies of immunosuppressive actions of viruses show that depletion of B lymphocytes, occurring after chemical bursectomy, results in a preventive effect of experimental infection of birds (Fitzgerald and Reed 1991). In our study, no lymphatic cells were evaluated, but we can presume that a decreased production of antibodies was due to temporary changes in CD4 CD8 populations, as reported by Suresh and Sharma (1995). It seems quite likely that this was also connected with the effect of vaccines on spleen cells, since the impact of the spleen on immunological response is remarkable (Graczyk et al. 1998, 2003; Rautenschlein and Sharma 1999).

Clinical observations and the studies of cyclosporine-treated birds suggest that $\mathrm{T}$ lymphocytes, and at the same time, cellular response can play an important role in the pathogenesis of MSD and responses to MSDV infections (Fitzgerald et al. 1995). The reactivity of T-cells in birds is evaluated using delayed-type hypersensitivity response to the administered T-cell mitogen (Parmentier et al. 1998; B oa-Amponsem et al. 1999).

The analysis of cellular response with the use of DTH test did not show any significant differences between HEV-vaccinated and non-vaccinated pheasants. At the same time, the results obtained in the study are in agreement with the suggestions of other authors who claim that the part of the body into which a mitogen is administered is of no importance. With significant differences in extreme values of the index noted, only some increasing tendencies were observed in WI and TI of HEV-vaccinated pheasants. These results are in agreement with the reports of Fitzgerald et al. (1992), who found that pheasants which had a contact with an MSD virus, showed a changed capability of T-lymphocytes for transformations. In our experiment, cellular response was assessed only once, 14 days after HEV inoculation, therefore, it is difficult to say whether the results of the DTH test reflect constant reactivity of the system, or they just illustrate a transient phase of the virus activity during immunogenesis.

We can state that the results obtained in our experiment are in concurrence with those obtained by other authors who studied the immunosuppressive effects of simultaneous vaccinations. Besides, they also show that consecutive overloading of pheasants with antigens can result in a reduced response of the birds to other antigens, which should be taken into consideration when scheduling prophylactic vaccinations for this species.

\section{Humorální a celulární imunitní odpověd bažantů vakcinovaných proti Newcastleské nemoci a hemorrhagické enteritidě}

Cílem pokusu bylo určit zda a v jaké míře může preventivní vakcinace proti Newcastleské chorobě (ND) a hemorrhagické enteritidě (HE) ovlivnit humorální a celulární imunitní odpověd' u bažantů. Vyhodnocení míry humorální imunitní odpovědi bylo provedeno na základě titru aglutininu po podání antigenu, celulární imunita byla hodnocena alergenodiagnostickým testem (DTH). Bažanti byli 1., 28. a 56. den po vylíhnutí očkováni proti Newcastleské nemoci (ND). Kromě této vakcinace byla části ptákủ 49. den po vylíhnutí podána vakcína proti HEV v pitné vodě (virus hemorrhagické enteritidy). Čtrnáct dní po vakcinaci proti HEV bylo ptákủm intravenózně podáno $0,5 \mathrm{ml} 10 \%$ SRBC (suspenze ovčích červených krvinek). S podáním SRBC byla současně provedena alergenodiagnostika intradermální aplikací fytoheaglutininu (PHA). U bažantů vakcinovaných proti NDV i HEV byl titr specifických anti-SRBC aglutininů signifikantně nižší $(p<0,05)$ než u těch vakcinovaných pouze proti ND. Též se ukázalo, že $43 \%$ ze všech specifických anti-SRBC protilátek u ptáků vakcinovaných proti NDV bylo rezistentních k 2-merkaptoethanolu, zatímco u ptáků vakcinovaných proti HEV jich bylo rezistentních $75 \%$. U alergenodiagnostického testu nebyly 
zaznamenány žádné signifikantní rozdíly. Jen u bažantů vakcinovaných proti HEV byla zjištěna tendence ke zvýšené hodnotě odpovědi. Výsledky potvrzují pozorování o imunosupresivním efektu souběžné vakcinace. Také ukazují, že přesycení/přetížení bažantů mnoha antigeny (ND a HEV vakcinace) může oslabit humorální imunitní odpověd na podané SRBC.

\section{References}

AHMAD J, SHARMA JM 1993: Protection against haemorrhagic enteritis and Newcastle disease in turkeys by embryo vaccination with monovalent and bivalent vaccines. Avian Dis 37: 485-491

BOA-AMPONSEM K, LARSEN CT, DUNNINGTON EA, SIEGEL PB 1999: Immunocompetence and resistance to marble spleen disease of broiler- and layer-type pure lines of chickens. Avian Pathol 28: 397-384

CARLSON HC, AL-SHEIKLY F, PETTIT JR, SEAWRIGHT GL 1974: Virus particles in spleens and intestines of turkeys with haemorrhagic enteritis. Avian Dis 18: 67-73

DOHMS JE, METZ A 1991: Stress mechanisms of immunosuppression. Vet Immunol Immunopat 30: 89-109

DOMERMUTH CH, GROSS WB, SCHWARTZ LD, MALLISON ET, BRITT L 1979: Vaccination of ring-necked pheasant for marble spleen disease. Avian Dis 23: 30-38

FITZGERALD SD, FITZGERALD AL, REED WM, BURNSTEIN T 1992: Immune function in pheasants experimentally infected with marble spleen disease virus. Avian Dis 36: 410-414

FITZGERALD SD, REED WM, FURUKAWA AM, ZIMELS E, FUNG L 1995: Effect of T-lymphocyte depletion on the pathogenesis of marble spleen disease virus infection in ring-necked pheasants. Avian Dis 39: 68-73

FITZGERALD SD, REED WM 1989: A review of marble spleen disease of ring-necked pheasants. J Wildlife Dis 25: $455-461$

FITZGERALD SD, REED WM 1991: Pathogenesis of marble spleen disease in bursectomized and nonbursectomized ring-necked pheasants following oral inoculation with cell-culture-propagated virus. Avian Dis 35: $579-584$

GANAPATHY K, CARGILL P, MONTIEL E, JONES RC 2005: Interaction between live avian pneumovirus and Newcastle disease virus vaccines in specific pathogen free chickens. Avian Pathol 34: 297-302

GRACZYK S, KURYSZKO J, MADEJ J 2003: The reactivity of spleen germinal centres in immunized and ACTH treated chickens. Acta Vet Brno 72: 523-531

GRACZYK S, MADEJ J, PLISZCZAK-KRÓL A 1998: The influence of splenectomy on humoral and cellular immune response and morphology of central lymphatic organs in the chickens immunized by different type of antigens. Sci Lett (Wroclaw, Agric. University) 58: 7-15 (in Polish)

GRACZYK S, SLOWIK J, ORDA J 2000: The influence of Tolpa Peat Preparation (TPP) on the course of humoral response in chickens fed with fodder containing animal protein of livex origin. Bulletin of the Polish Academy of Sciences Biological Sciences 48: 293-304

GRACZYK S, ZAWADZKI W, CZERSKI A, PLISZCZAK-KRÓL A, KOTONSKI B 2004: Delayed type hypersensitivity reaction (DTH) in the turkeys treated with beta adrenergic antagonist and ACTH. EJPAU Electronic Journal of Polish Agricultural Universities, Series Veterinary Medicine 7 (2)

GROSS WB 1967: Lesions of haemorrhagic enteritis. Avian Dis 11: 684-693

KULIKOVA L, JURAJDA V, JURANOVA R 2004: Effects of infectious bursal disease vaccination strains on the immune system of leghorn chickens. Acta Vet Brno 73: 205-209

KUNZE KL, FITZGERALD SD, RICHARD A, BALANDER R, REED WM 1996: Variation in response of four lines of ring-necked pheasants to infection with marble spleen disease virus. Avian Dis 40: 306-311

NAGARAJA KV, EMERY DA, PATEL BJ, POMEROY BS, NEWMAN JA 1982: In vitro evaluation of Blymphocyte function in turkeys infected with haemorrhagic enteritis wirus. Am J Vet Res 43: 502-504

PARMENTIER HK, REILINGH GD, NIEUWLAND MGB 1998: Kinetic and immunohistochemical characteristics of mitogen-induced cutaneous hypersensitivity in chickens selected for antibody responsiveness. Vet Immunol Immunopat 66: 367-376

PIERSON FW, FITZGERALD SD 2003: Haemorrhagic enteritis and related infections. In: Saif Y.M, Diseases of Poultry $11^{\text {th }}$ ed., Iowa Press, pp. 237-247.

PIERSON FW, LARSEN CT, DOMERMUTH CH, 1996: The production of colibacillosis in turkeys following sequential exposure to Newcastle disease virus or Bordetella avium, avirulent haemorrhagic enteritis virus, and Escherichia coli. Avian Dis 40: 837- 840

RAUTENSCHLEIN S, SHARMA JM 1999: Response of turkeys to simultaneous vaccination with haemorrhagic enteritis and Newcastle disease viruses. Avian Dis 43: 286-292

SHARMA JM 1994: Response of specific-pathogen-free turkeys to vaccinates derived from marble spleen disease virus and haemorrhagic enteritis virus. Avian Dis 38: 523-530

SLOWIK J, GRACZYK S, GOLNIK W, PAWESKA J 1990: Immunological response of bursectomized and nonbursectomized chickens inoculated with Newcastle disease virus (NDV), after administration of sheep red blood cells (SRBC) or bovine serum albumin (BSA). Pol Arch Wet 30: 101-112 (in Polish)

SPONENBERG DP, DOMERMUTH CH, LARSEN CT 1985: Field outbreaks of colibacillosis of turkeys associated with haemorrhagic enteritis virus. Avian Dis 29: 838-842 
SURESH M, SHARMA JM 1995: Haemorrhagic enteritis virus induced changes in the lymphocyte subpopulations in turkeys and the effect of experimental immunodeficiency on viral pathogenesis. Vet Immunol Immunopat 45 : $139-150$

TALEBI A, POURBAKHSH SA, DOROSTKAR K 2005: Effects of vaccination routes against IB on performance and immune responses of broiler chickens. Int J Poultry Sci 4: 795-798

TRAMPEL DW, METEYER CU, ARTUR A, BICKPORD AA 1992: Haemorrhagic enteritis virus inclusions in turkey renal tubular epithelium. Avian Dis 36: 1086-1091

WIELICZKO A, TOMANEK B, KUCZKOWSKI M 2003: Prevalence of infectious diseases in ring-necked pheasant flocks in Poland. Pol J Vet Sci 6: 177-182 